Original Article

\title{
REVERSAL OF CLONIDINE-INDUCED HYPOTHERMIA BY DECAFFEINATED TEA/COFFEE EXTRACT, AND THEIR FRACTIONS IN MICE
}

\author{
BALU U. SALVE1 ${ }^{*}$, CHANDRAKANT R. KOKARE1, SANJAY B. KASTURE²
}

${ }^{1}$ STES's Sinhgad Institute of Pharmacy, Narhe, Pune, 411041 (MS), India, ${ }^{2}$ Pinnacle Biomedical Research Institute, Bhopal, 462003 (MP), India

Email: balu.salve@gmail.com

Received: 27 Apr 2021, Revised and Accepted: 05 Jun 2021

\section{ABSTRACT}

Objective: To study the effect of decaffeinated tea extract (DTE) and decaffeinated coffee extract (DCE) and their respective fractions viz: chloroform fractions (DTCf and DCCf), ethyl acetate fractions (DTEa and DCEa), diethyl ether fractions (DTDe and DCDe) and acetone-water fractions (DTAw and DCAw) against clonidine-induced hypothermia in mice.

Methods: Clonidine $(0.1 \mathrm{mg} / \mathrm{kg}$, i. p.) administered to a group of mice pretreated $30 \mathrm{~min}$ before with the dose of DTE or DCE or their respective fractions. Rectal temperature was measured at the time of clonidine administration and thereafter at every $30 \mathrm{~min}$ up to $2 \mathrm{~h}$ test period.

Results: DTE 200 DTE 300 has significantly inhibited clonidine-induced hypothermia. Among the fractions tested, DTE fraction-DTEa 100 and 200 and DCE fractions DCDe 200 and DCAw 200 significantly $(\mathrm{p}<0.0001)$ reversed clonidine-induced hypothermia; the effect of DTEa was found to be more sustained.

Conclusion: Both, the decaffeinated tea and coffee contain ingredients that reverse clonidine-induced hypothermia, but they are required to do so in very large doses which are not achievable with normally administered doses of decaffeinated tea or coffee.

Keywords: Polyphenol, Flavonoids, Hypothermia, Decaffeinated

(c) 2021 The Authors. Published by Innovare Academic Sciences Pvt Ltd. This is an open access article under the CC BY license (https://creativecommons.org/licenses/by/4.0/) DOI: https://dx.doi.org/10.22159/ijpps.2021v13i8.41939. Journal homepage: https://innovareacademics.in/journals/index.php/ijpps.

\section{INTRODUCTION}

Animals have developed different methods of maintaining an ideal body temperature during the course of evolution. Cold-blooded (ectothermic) animals cannot regulate their body temperature internally so their body temperature varies according to their environment. In contrast, warm-blooded (endothermic) animals including humans, maintain a constant body temperature by adapting endogenous mechanisms specifically for heat production [1]. In humans, core body temperature is normally maintained within a tight range $\left(36.5-37.5^{\circ} \mathrm{C}\right)$. Thermoregulatory inputs are modulated in the spinal cord and brain stem; integrated in the preoptic region of the anterior hypothalamus. Fine balance between nor-adrenaline (NA) and serotonin $(5-\mathrm{HT})$ controls the body temperature set point [2].

Clonidine is a non-selective $\alpha_{2}$ adrenergic agonist, clinically used in the management of surgical patients as it is known to possess sedative, analgesic, and anaesthetic sparing property [3] Specifically, it stimulates $\alpha_{2 B}$ adrenergic receptor subtype that causes initial direct vasoconstriction in peripheral vascular smooth muscles. However, activation of $\alpha_{2 \mathrm{~A}}$ adrenergic receptor subtype causes hypotension by inhibiting central sympathetic outflow as well as the release of NA from sympathetic nerves $[3,4]$. Clonidine produces dose-dependent hypothermia. It has been suggested that clonidine has inhibitory actions on both 5-HT mediated responses in the spinal cord and its turnover as well [5]

There is an increased desire to drink tea or coffee when the body temperature falls down; because drinking tea or coffee produces a feeling of warmth. Decaffeinated tea and coffee are available in the market and it is not known what type of effect the decaffeinated tea or coffee will have on the patient and normal individual. In the present study, the effect of decaffeinated tea extract (DTE) and decaffeinated coffee extract (DCE) and their respective fractions in various solvents was evaluated on clonidine-induced hypothermia in mice. The decaffeinated tea and coffee contains a high amount of polyphenols. Polyphenols effectively elevates concentrations of 5-HT and NA in the brain areas which regulate body temperature [6]. In some reported studies, the decaffeinated tea and coffee extracts were successively fractionated with chloroform (to remove traces of caffeine and get al. kaloid rich fraction) [7, 8]; ethyl acetate (to get flavanol from tea having antioxidant activity) [8]. The major flavonoid of tea and coffee is Epigallocatechin gallate (EGCG) which is poorly soluble in diethyl ether $[9,10]$. Hence, the diethyl ether fraction will not reduce the amount of EGCG and the acetone fraction will therefore contain the highest amount of EGCG. Ingestion of coffee polyphenols improves skin permeability barrier function and hydration, with a concomitant improvement in microcirculatory function, leading to efficacy in the alleviation of mildly xerotic skin [11]. Decaffeinated coffee prevents scopolamine-induced memory impairment in rats [12]. Decaffeinated coffee polyphenols such as chlorogenic acid, ferulic acid, hydroxycinnamic acid, flavonoids, flavanones and anthocyanins are known to reduce the risk of cardiovascular diseases $[13,14]$. Chlorogenic acid acts as an efficient neuroprotector in the management of neurodegenerative disorders [15] and caffeic acid possesses good antioxidant activity [16].

Decaffeinated green and black tea polyphenols decrease dietinduced weight gain in obese mice [17]. Therefore, four fractions of both, decaffeinated extracts of tea and coffee were used to study their effects on clonidine-induced hypothermia in mice.

\section{MATERIALS AND METHODS}

\section{Animals}

Albino mice were obtained from Global Bioresearch Solutions Pvt. Ltd., Tal. Bhor, Dist. Pune, Maharashtra. Mice weighing 22-25 g were housed in groups of five under standard laboratory conditions (ambient temperature of $25 \pm 1{ }^{\circ} \mathrm{C}$ and relative humidity $45-55 \%$ ). Light/dark cycle of $12: 12 \mathrm{~h}$ was strictly maintained during the experiment. The animals were fed ad libitum with standard feed and water. They were deprived of food $12 \mathrm{~h}$ before testing but had free access to water. All the experiments were carried out between 08:00 and 14:00 $\mathrm{h}$ 
The protocol of animal experiments was approved by Institutional Animal Ethical Committee (IAEC), approval no. SIOP/IAEC/2019/10. The animal house facility of STES's Sinhgad Institute of Pharmacy, Narhe, Pune (SIOP) is registered under the Committee for the Purpose of Control and Supervision on Experiments on Animals (CPCSEA), Reg. No. 1139/a/07/CPCSEA.

\section{Drugs and chemicals}

The decaffeinated tea extract (DTE), decaffeinated coffee extract (DCE) and its respective fractions in various solvents were the test samples. Clonidine hydrochloride (Neon Laboratories, Mumbai, India), caffeine (Sigma, USA) and Antidep (imipramine) (Torrent Pharmaceuticals Ltd., Mumbai, India) were used for the study; imipramine was used as the reference standard. Solvents viz: chloroform, ethyl acetate, diethyl ether and acetone (Research-Lab Fine Chem Industries, Mumbai, India) were used for obtaining respective fractions.

\section{Preparation of extract and fractions}

Decaffeinated tea powder-"Tetley decaf" and decaffeinated coffee powder-"Nescafe decaff" were purchased from Dorabji, MG Road, Camp, Pune, Maharashtra. Each of the crude material was separately extracted using an acetone-water solvent system (80:20) by standard maceration method of extraction. The decaffeinated tea extract (DTE) and decaffeinated coffee extract (DCE) obtained were concentrated in a rotating evaporator under reduced pressure; kept in lyophilizer for $72 \mathrm{~h}$ until dry residue was obtained. The quantity, $80 \%$ of DTE and DCE obtained, was further fractionated using a various solvents with increasing polarity (diethyl ether, chloroform, ethyl acetate and acetone-water). DTE and DCE fractions obtained include chloroform fractions-DTCf and DCCf; ethyl acetate fractionsDTEa and DCEa; diethyl ether fractions-DTDe and DCDe and acetone-water fractions-DTAw and DCAw respectively [18].

\section{Dose preparation}

Mice were injected with clonidine $(0.1 \mathrm{mg} / \mathrm{Kg}$, i. p.), caffeine $(25$ $\mathrm{mg} / \mathrm{Kg}$, i. p.), DTE $(100,200$ and $300 \mathrm{mg} / \mathrm{kg}$, i. p.), DTE fractions (DTCf, DTEa, DTDe and DTAw, 100 and $200 \mathrm{mg} / \mathrm{kg}$, i. p. each), DCE $(100,200$ and $300 \mathrm{mg} / \mathrm{Kg}$, i. p.), DCE fractions (DCCf, DCEa, DCDe and DCAw, 100 and $200 \mathrm{mg} / \mathrm{kg}$, i. p. each) and reference standard imipramine $(20 \mathrm{mg} / \mathrm{kg}$, i. p.). All drug solutions were prepared in pyrogen-free glassware, heated in a hot air oven (for $5 \mathrm{~h}$ at $180^{\circ} \mathrm{C}$ ) before use. Drugs and test samples were dissolved in distilled water immediately before the use and administered intraperitoneally to the mice in a volume of $1 \mathrm{ml} / \mathrm{kg}$.

\section{Measurement of hypothermia}

In this experiment, hypothermia was assessed by measuring rectal temperature. The mouse was hand-restrained and placed on a horizontal surface (cage lid). The tail was lifted and the thermometer probe (covered with Vaseline) was gently inserted into the rectum to a fixed depth (typically up to $2 \mathrm{~cm}$ ). It was kept at the position for 8-10 s and temperature was recorded. Mice were pre-treated with either extracts or specific fractions $30 \mathrm{~min}$ before clonidine administration. Rectal temperature was measured for $2 \mathrm{~h}$, i.e. immediately after clonidine administration and thereafter for every $30 \mathrm{~min}$ up to $2 \mathrm{~h}$. Average normal body temperature range of mice was reported to be $36.5-38{ }^{\circ} \mathrm{C}$ [19].

\section{Statistical analysis}

The mean $\pm S E M$ in groups was calculated $(n=5)$, the statistical significance of differences between the means of group analyzed by two-way analysis of variance (ANOVA). An analysis of individual between-group comparisons was carried out using Tukey's multiple comparison tests, $P<0.05$ is considered to be statistically significant $\left({ }^{\circledR} P<0.0001,+P<0.001\right.$ and $\left.{ }^{\infty} P<0.05\right)$.

\section{RESULTS}

\section{Yield of extracts and fractions}

The yield of dry decaffeinated tea extract (DTE) obtained was $50 \mathrm{~g}$. DTE was subjected to fractionation with mentioned solvents; the yield of respective fractions were noted viz: diethyl ether fraction
(DTDe), $4.2 \mathrm{~g}$; chloroform fraction (DTCf), $2.5 \mathrm{~g}$; ethyl acetate fraction (DTEa), $8.5 \mathrm{~g}$ and acetone-water fraction (DTAw), $18.5 \mathrm{~g}$.

The yield of dry decaffeinated tea extract (DCE) obtained was $65 \mathrm{~g}$. DCE was further subjected to fractionation with mentioned solvents; the yield of respective fractions were noted viz: diethyl ether fraction (DCDe), $6.5 \mathrm{~g}$; chloroform fraction (DCCf), $4 \mathrm{~g}$; ethyl acetate fraction (DCEa), $10 \mathrm{~g}$ and acetone-water fraction (DCAw), $25 \mathrm{~g}$.

\section{Effect on clonidine-induced hypothermia}

In the present study, DTE 200 and DTE 300 significantly $(\mathrm{P}<0.0001)$ inhibited clonidine-induced hypothermia at 60 and $90 \mathrm{~min}$ while DCE could not produce a pronounced effect on hypothermia as compare to control (fig. 1). Among the DTE fractions tested, the only fraction, DTEa at the doses 100 and $200 \mathrm{mg} / \mathrm{kg}$ significantly reversed hypothermia $(\mathrm{P}<0.0001)$ compared to control group. The effect was seen at $60 \mathrm{~min}$ that persisted for $1 \mathrm{~h}$ (i.e. up to $2 \mathrm{~h}$ test period) (fig. 2). The DCE fractions, DCDe 200 and DCAw 200 could inhibit hypothermia; significant effect $(\mathrm{P}<0.0001)$ was noted only at 60 and 90 min compared to control group; indicating the said effect sustained for $30 \mathrm{~min}$ approx (fig. 3). In common, caffeine $(25 \mathrm{mg} / \mathrm{kg}$, i.p.) significantly $(\mathrm{P}<0.0001)$ reversed clonidine-induced hypothermia from 30 min onwards compared to control group; it explicates a prolonged duration of action. None of the extracts or fractions per se increased clonidine-induced hypothermia.

Effect of DTE and DCE on clonidine- induced hypothermia

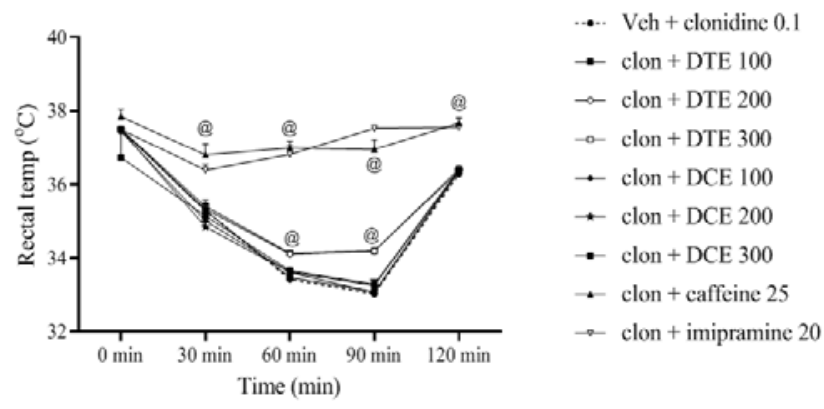

Fig. 1: Effect of DTE and DCE on clonidine-induced hypothermia in mice

Data were expressed as mean \pm SEM., $n=5$, statistical significance was determined by Two-way analysis of variance (ANOVA) followed by Tukey's multiple comparison test; ${ }^{\circledR} P<0.0001$ compared to vehicle+clonidine group. Only DTE 200 and 300 significantly inhibited the hypothermia.

Dose: clonidine $(0.1 \mathrm{mg} / \mathrm{kg}$, i. p.), caffeine $(25 \mathrm{mg} / \mathrm{kg}$, i. p.), imipramine $(20 \mathrm{mg} / \mathrm{kg}$, i. p.) and DTE and DCE $(100,200$ and 300 $\mathrm{mg} / \mathrm{kg}$, i. p.).

Effect of DTE Fractions on clonidine- induced hypothermia

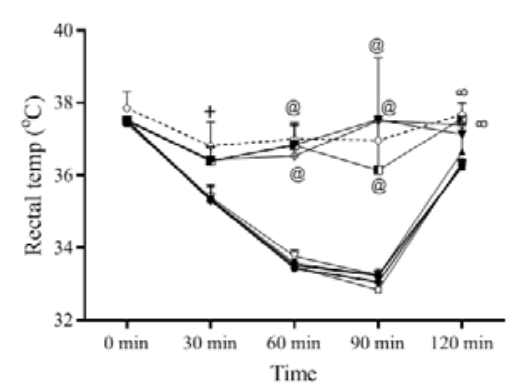

- Veh + clonidine 0.1

$\rightarrow$ clon + DTCf 100

- clon + DTCf 200

$\rightarrow$ clon + DTEal 00

$\rightarrow$ clon + DTEa 200

$\rightarrow$ clon + DTDe100

-o- clon + DTDe 200

$\rightarrow$ clon + DTAw 100

$\rightarrow$ clon + DTAw 200

clon + caffeine 25

- - clon + imipramine 20

Fig. 2: Effect of DTE fractions on clonidine-induced hypothermia in mice 
Data were expressed mean \pm SEM., $n=5$, statistical significance was determined by Two-way analysis of variance (ANOVA) followed by Tukey's multiple comparison test; ${ }^{\circledR} P<0.0001,+P<0.001,{ }^{\infty} P<0.05$ compared to vehicle+clonidine group. Only DTEa significantly inhibited hypothermia.

Dose: clonidine (0.1 $\mathrm{mg} / \mathrm{kg}$, i. p.), caffeine $(25 \mathrm{mg} / \mathrm{kg}$, i. p.), imipramine $(20 \mathrm{mg} / \mathrm{kg}$, i. p.) and DTE fractions-DTCf, DTEa, DTDe and DTAw (100 and $200 \mathrm{mg} / \mathrm{kg}$, i. p.).

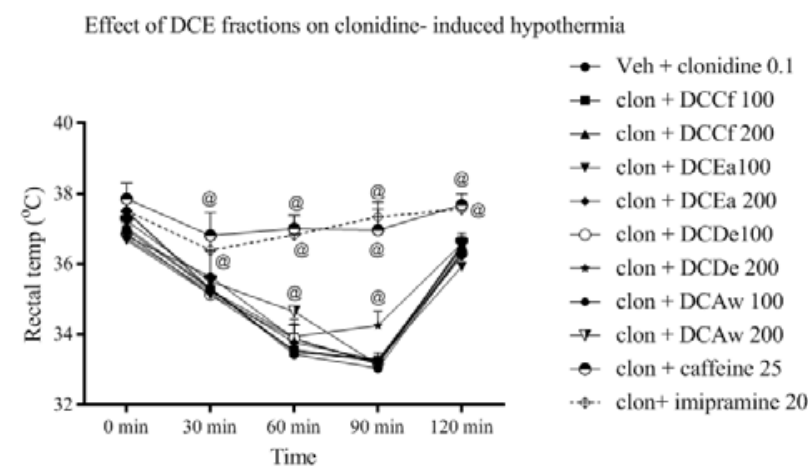

Fig. 3: Effect of DCE fractions on clonidine-induced hypothermia in mice

Data were expressed as mean \pm SEM., $n=5$, statistical significance was determined by Two-way analysis of variance (ANOVA) followed by Tukey's multiple comparison test; @ ${ }^{\circ}<0.0001$ compared to vehicle+clonidine group. Only DCDe 200 and DCAw 200 significantly inhibited hypothermia.

Dose: clonidine $(0.1 \mathrm{mg} / \mathrm{kg}$, i. p.), caffeine (25 mg/kg, i. p.), imipramine $(20 \mathrm{mg} / \mathrm{kg}$, i. p.) and DCE fractions-DCCf, DCEa, DCDe and DCAw (100 and $200 \mathrm{mg} / \mathrm{kg}$, i. p.).

\section{DISCUSSION}

Clonidine-induced hypothermia has a complex phenomenon. Hypothermia is associated with clonidine overdose in humans [20]; overdose of another $\alpha_{2}$ receptor agonist guanabenz, a structural analogue of clonidine, also shares the same pharmacological properties [21]. In mice, clonidine-induced hypothermia has been related to its ability to cross the blood-brain barrier and interact with central $\alpha_{2}$ receptors which contribute to thermoregulation [22]. However, in rats, clonidine elicits hypothermia via activation of central 5-HT pathways which resulted in decreased metabolic heat production and/or increased heat loss through cutaneous vasodilation [23].

Hypothermia is one of the adverse drug reactions of drugs like antipsychotics that commonly require hospitalization [24]. Both, conventional and atypical antipsychotics cause hypothermia but atypical antipsychotics have a lower risk [25]. Hypothermia particularly in advanced age, cerebrovascular accident, hypothyroidism, sepsis, benzodiazepine use, alcohol intoxication, kidney or liver failure could be life-threatening [26]. The effects of undesired hypothermia in trauma are more in numbers and complex too [27]. In humans, sustained hypothermia has been demonstrated to slow down enzyme activity [28]. Deep hypothermia (temperature $<33{ }^{\circ} \mathrm{C}$ ) inhibits platelet function and coagulation mechanism [29]. Hypothermia may induce arrhythmias, cause trauma-associated coagulopathy. From an immunological perspective, hypothermia may diminish the inflammatory response and increase the risk of pneumonia [30]. Hypothermic patients are also prone to surgical wound infections, delayed suture removal and extended hospitalization [31].

Imipramine is reported to inhibit reserpine-induced hypothermia [32]. Single administration of imipramine is known to activate 5$\mathrm{HT}_{1 \mathrm{~A}}$ receptors and inhibit the hypothermia induced by the $5-\mathrm{HT}_{1 \mathrm{~A}}$ receptor full agonist-8-hydroxy-2-[di-n-propylamino] tetralin (8-
OH-DPAT). However, this inhibitory effect was blocked by $5-\mathrm{HT}_{2 \mathrm{~A}}$ receptor antagonist ketanserin [33]. It suggests that the inhibition of hypothermia by an acute dose of imipramine may be associated with activation of 5-HT $2 \mathrm{~A}$ receptor subtype of serotonin; however, if administered chronically, it has been found to cause hypothermia.

Clonidine-induced cutaneous vasodilatation may reduce the core-toperiphery temperature gradient and enhance body heat redistribution [34]. In hypothermia, onset and duration are important parameters ensuring therapeutic benefits and avoiding potential risks. One study reports that peak plasma concentration of clonidine and its effects occur within $30 \mathrm{~min}$ of its oral administration [35].

Warm tea or coffee provides a feeling of well-being to the patient having hypothermia. Caffeine promotes hyperthermia [36]. It is reported that plant-derived polyphenols have a remarkable antidepressant activity [37] and they inhibit hypothermia [38]. Though tea component, catechin raises body temperature [39], there is no literature available on the effect of decaffeinated tea/coffee on hypothermia.

Based on the hypothesis proposed by Lin et al. [40], clonidine may act on 5-HT-ACh pathway within preoptic anterior hypothalamus to exert the hypothermic action. Hypothalamus is richly innervated by both serotonergic and cholinergic nerve fibres. Clonidine increases brain 5HT level and ACh level. In general, hypothermia can be reversed by depletion of 5-HT and/or antagonism of ACh action. It is achieved by 5-HT depletion by 5, 7-dihydroxytryptaminne or blockade of 5-HT receptor with cyproheptadine or cholinoceptors with atropine. Apart from this, another mechanism of hypothermia reversal came into sight; that was observed in case of imipramine. Despite of being 5-HT uptake inhibitor, it has caused reversal of hypothermia by activation of 5-HT2A receptor subtype of 5-HT on acute treatment [33].

Major Flavanol content was extracted from green tea by ethyl acetate, while most of the alkaloids were in the chloroform fraction. Flavanol showed very strong antioxidant activity and lipoxygenase inhibition [8]. One of the major flavonoids obtained from green tea is Epigallocatechin gallate (EGCG). An optimized method of green tea extraction yielded EGCG $286.87 \mathrm{mg} / \mathrm{g}$ dry weight [41]. One of the studies mentioned that petroleum ether and chloroform fractions of ethanolic extract of tea when analyzed tested positive for terpenoids and steroids [42].

In our study, clonidine-induced hypothermia was reversed by DTE $(200$ and $300 \mathrm{mg} / \mathrm{kg}$, i. p.). The activity is highly significant $(\mathrm{P}<0.0001)$ compared to the control group. This effect may be the due presence of active phenolic compounds present in the extract. Further, flavonoids/tannins content in its ethyl acetate fraction (DTEa) has resulted in a significant increase in the body temperature till the end of $2 \mathrm{~h}$ observation period. In comparison to the parent extract (DTE), the effect produced by DTEa lasted longer. DCE as a whole was found to be inert in this case; however, its diethyl ether fraction (DCDe) at the dose $200 \mathrm{mg} / \mathrm{kg}$ and acetonewater fraction (DCAw) at the dose $200 \mathrm{mg} / \mathrm{kg}$ could inhibit hypothermia for a very short time. Here, in all the observations of hypothermia reversal, one common thing was observed; test substances had profound action particularly at $1 \mathrm{~h}$ that could be considered as peak effect.

\section{CONCLUSION}

As compared to caffeine and imipramine, decaffeinated tea required very high doses (200 and $300 \mathrm{mg} / \mathrm{kg}$ i. p.) to reverse clonidineinduced hypothermia and decaffeinated coffee had no significant effect. The fractions of both decaffeinated tea and coffee also had very feeble effect on clonidine-induced hypothermia.

\section{ACKNOWLEDGEMENT}

Authors are thankful to STES's Sinhgad Institute of Pharmacy, Pune for providing the necessary infrastructure and lab facilities for the research work. The corresponding author-Mr. Balu Salve is Ph D. Research Scholar at Jawaharlal Nehru Technological University (JNTUH), Hyderabad (TS), India.

\section{FUNDING}




\section{AUTHORS CONTRIBUTIONS}

BS and SK designed the protocol and prepared the manuscript. SK and CK interpreted the scientific data and all the author read and approved the manuscript.

\section{CONFLICTS OF INTERESTS}

All the listed authors do not have a conflict of interest.

\section{REFERENCES}

1. Thomas K, Ulf S. Effect of hypothermia on haemostasis and bleeding risk: a narrative review. J Int Med Res 2019;47:3559-60.

2. Feldberg W, Myers RD. A new concept of temperature regulation by amines in hypothalamus. Nature 1963;200:1325.

3. Mizobe T, Maze M. Alpha 2-adrenoceptor agonists and anesthesia. Int Anesthesiol Clin 1995;33:81-102.

4. Mizobe T, Maze M. Molecular pharmacology of $\alpha_{2}$ adrenoceptors; relevance to anesthesia. Anesthesiol Clin North Am Ann Anesth Pharmacol 1997;1:1-26.

5. Franz DN, Hare BD, Neumayr RJ. Depression of sympathetic preganglionic neurons by clonidine. Evidence for stimulation of 5-HT receptors. Clin Exp Hypertens 1978;1:115-40.

6. Liu Y, Jia G, Gou L, Sun L, Fu X, Lan N, et al. Antidepressant-like effects of tea polyphenols on a mouse model of chronic unpredictable mild stress. Pharmacol Biochem Behav 2013;104:27-32.

7. Row KH, Jin Y. Recovery of catechin compounds from Korean tea by solvent extraction. Bioresour Technol 2006;97:790-3.

8. Xie B, Shi H, Chen Q, Ho CT. Antioxidant properties of fractions and polyphenol constituents from green, oolong and black teas. Proc Natl Sci Counc Repub China B 1993;17:77-84.

9. Krol K, Gantner M, Tatarak A, Hallmann E. The content of polyphenols in coffee beans as roasting, origin and storage effect. Eur Food Res Technol 2020;246:33-9.

10. Liu B, Kang Z, Yan W. Synthesis, stability, and antidiabetic activity evaluation of (-)-Epigallocatechin gallate (EGCG) palmitate derived from natural tea polyphenols. Molecules 2021;26:393.

11. Fukagawa S, Haramizu S, Sasaoka S, Yasuda Y, Tsujimura H, Murase T. Coffee polyphenols extracted from green coffee beans improve skin properties and microcirculatory function. Biosci Biotechnol Biochem 2017;81:1814-22.

12. Jang YJ, Kim J, Shim J, Kim CY, Jang JH, Lee KW, et al. Decaffeinated coffee prevents scopolamine-induced memory impairment in rats. Behav Brain Res 2013;245:113-9.

13. Tresserra Rimbau A, Medina Remon A, Estruch R, Lamuela Raventos RM. Coffee polyphenols and high cardiovascular risk parameters. In: Preedy VR. editor. Coffee in Health and Disease Prevention. $1^{\text {st }}$ ed. London: Academic Press; 2015. p. 387-94.

14. Godos J, Castellano S, Ray S, Grosso G, Galvano F. Dietary polyphenol intake and depression: results from the Mediterranean healthy eating, lifestyle and aging (MEAL) study. Molecules 2018;23:999.

15. Budiman A, Lutfhi A, Muchtaridi M. The stability of chlorogenic acid in syrup of Coffee arabica (Coffee arabica L.) extract with decaffeination process. Asian J Pharm Clin Res 2017;10:1-4.

16. Zahran F, Al-Hussaini AS, El-Shehabi ME. Antidiabetic activity of caffeic acid and 18ß-glycyrrhetinic acid and its relationship with the antioxidant property. Asian J Pharm Clin Res 2015;8:229-35.

17. Henning SM, Yang J, Hsu M, Lee RP, Grojean EM, Ly A, et al. Decaffeinated green and black tea polyphenols decrease weight gain and alter microbiome populations and function in dietinduced obese mice. Eur J Nutr 2018;57:2759-69.

18. Babbar N, Oberoi HS, Sandhu SK, Bhargav VK. Influence of different solvents in the extraction of phenolic compounds from vegetable residues and their evaluation as natural sources of antioxidants. J Food Sci Technol 2014;51:2568-75.

19. Kasture S, Pawar A, Kasture A, Foddis C, Frau MA, Maxia A. Effect of ethanolic extract of Rubia peregrina L. (Rubiaceae) on monoamine-mediated behaviour. Nat Prod Res 2011;25:1950-4.

20. Anderson RJ, Hart GR, Crumpler CP, Lerman UT. Clonidine overdose: report of six cases and review of the literature. Ann Emerg Med 1981;10:107-12.
21. Jeanmarie P, Robert SH, Bruce J, Judd EH. Guanabenz induced hypothermia in a poisoned elderly female. J Toxicol Clin Toxicol 1994;32:445-9.

22. McLennan PL. The hypothermic effect of clonidine and other imidazolidines in relation to their ability to enter the central nervous system in mice. Eur J Pharmmol 1981;69:477-82.

23. Lin MT, Chandra A, KO WC, Chen YM. Serotonergic mechanisms of clonidine-induced hypothermia in rats. Neuropharmacology 1981;20:15-21.

24. Van Marum RJ, Wegewijs MA, Loonen AJ, Beers E. Hypothermia following antipsychotic drug use. Eur J Clin Pharmacol 2007;63:627-31.

25. Zonnenberg C, Bueno-de-Mesquita JM, Ramlal D, Blom JD. Hypothermia due to antipsychotic medication: a systematic review. Front Psychiatry 2017;8:165.

26. Seeman MV, Emerita P. Antipsychotics, hypothermia, undressing, and death. Glob J Med Clin Case Rep 2017;4:1-3.

27. Vardon F, Mrozek S, Geeraerts T, Fourcade O. Accidental hypothermia in severe trauma. Anaesth Crit Care Pain Med 2016;35:355-61

28. Watts DD, Trask A, Soeken K, Perdue P, Dols S, Kaufmann C, et al. Hypothermic coagulopathy in trauma: effect of varying levels of hypothermia on enzyme speed, platelet function, and fibrinolytic activity. J Trauma 1998;44:846-54.

29. Livingston A, Low J, Morris B. Effects of clonidine and xylazine on body temperature in the rat. Br J Pharmacol 1984;81:189-93.

30. Thorsen K, Ringdal KG, Strand K, Soreide E, Hagemo J, Soreide $\mathrm{K}$. Clinical and cellular effects of hypothermia, acidosis and coagulopathy in major injury. Br J Surg 2011;98:894-907.

31. Nakajima Y, Mizobe T, Takamata A, Tanaka Y. Baroreflex modulation of peripheral vasoconstriction during progressive hypothermia in anesthetized humans. Am J Physiol Regul Integr Comp Physiol 2000;279:1430-6.

32. Frances $H$. Analysis of the nature of antagonism of the reserpine-induced hypothermia by imipramine. Naunyn Schmiedebergs Arch Pharmacol 1987;336:303-37.

33. Kitamura Y, Araki H, Shibata K, Gomita Y, Tanizaki Y. Modulation of 8-OH-DPAT-induced hypothermia by imipramine in rats. J Pharmacol Sci 2003;93:259-64.

34. Vassilieff N, Rosencher N, Sessler DI, Conseiller C, Lienhart A. Nifedipine and intraoperative core body temperature in humans. Anesthesiology 1994;80:123-8.

35. Bernard JM, Fulgencio JP, Delaunay L, Bonnet F. Clonidine does not impair redistribution hypothermia after the induction of anesthesia. Anesth Anal 1998;87:168-72.

36. McNamara R, Kerans A, O'Neill B, Harkin A. Caffeine promotes hyperthermia and serotonergic loss following coadministration of the substituted amphetamines, MDMA ("Ecstasy") and MDA ("Love"). Neuropharmacology 2006;50:69-80.

37. Bahramsoltani R, Farzaei MH, Farahani MS, Rahimi R. Phytochemical constituents as future antidepressants: a comprehensive review. Rev Neurosci 2015;26:699-719.

38. Ankad GM, Upadhya V, Pai SR, Hegde HV, Roy S, Kholkute SD. Total polyphenols, antioxidant and antimicrobial activity of leaves and stem bark extracts of Allophylus cobbe (L.) raeusch. Proc Natl Acad Sci India Sect B Biol Sci 2016;86:145-9.

39. Mohammed AA, Al-Hozab AA. +(-) catechin raises body temperature, changes blood parameters, improves oocyte quality and reproductive performance of female mice. Ind J Anim Res 2018;54:543-8.

40. Lin MT, Shian LR, Leu SY. Clonidine-induced hypothermia: possible involvement of cholinergic and serotonergic mechanisms. Naunyn Schmiedebergs Arch Pharmacol 1984;326:124-8.

41. Setyawan EI, Setyowati EP, Rohman A, Nugroho AK. Central composite design for optimizing the extraction of EGCG from green tea leaf (Camellia sinensis L.). Int J Appl Pharm 2018;10:211-6.

42. Seema, Kumar A, Aggarwal K, Kumar A. A pharmacognostical evaluation of Embelia ribes and Camellia sinensis: comparative studies of their anthelmintic activity. Int J Curr Pharm Res 2021;13:42-5. 